\title{
Community versus Market: A Note on Corporate Villages
}

\section{Citation}

Bates, Robert H., and Amy Farmer Curry. 1992. Community versus market: a note on corporate villages. American Political Science Review 86(2): 457-463.

\section{Published Version}

http://dx.doi.org/10.2307/1964233

\section{Permanent link}

http://nrs.harvard.edu/urn-3:HUL.InstRepos:3224743

\section{Terms of Use}

This article was downloaded from Harvard University's DASH repository, and is made available under the terms and conditions applicable to Other Posted Material, as set forth at http:// nrs.harvard.edu/urn-3:HUL.InstRepos:dash.current.terms-of-use\#LAA

\section{Share Your Story}

The Harvard community has made this article openly available.

Please share how this access benefits you. Submit a story.

Accessibility 


\title{
COMMUNITY VERSUS MARKET: A NOTE ON CORPORATE VILLAGES
}

\author{
ROBERT H. BATES Duke University \\ AMY FARMER CURRY University of Arkansas
}

W e return to the literature on collective villages and reexamine its central arguments. In doing so, we focus on an institution for allocating land that we call the Rule. As claimed by its advocates, the Rule secures land allocations that result in outcomes differing from those that would be achieved by markets. The outcomes are not constrained to be efficient. But the economic costs paid fail to secure the attainment of guarantees of subsistence, greater equality, or a greater sense of community resulting from the elimination of envy. However, in the face of high levels of risk, the form of collective property rights embodied in the Rule may create what we call "communities of (mis)fortune," in which no one can envy others' gains or losses resulting from the random shocks of nature.

B arrington Moore (1966) identified the peasantry as the revolutionary class of our time. The power of guerrilla forces in Vietnam rapidly convinced scholars of the validity of Moore's claim. Particularly when viewed from a developmental perspective, the revolutionary behavior of peasants posed deep analytic problems, however. Why should members of what arguably is a precapitalistic social formation stand at the forefront of modern revolutions?

Scholars offered competing answers to this question: dependency theory, ${ }^{1}$ classical Marxism, ${ }^{2}$ moral economy, ${ }^{3}$ and rational choice. ${ }^{4}$ Among the most heated of the resultant debates was that between the moral economists and the rational choice theorists. We reenter that debate, seeking to extend and deepen it by formalizing its central arguments.

Moral economists based their explanations of peasant revolution on an analysis of rural institutions, arguing that key peasant institutions (e.g., the corporate village) create collective, as opposed to private, property rights. They therefore support the attainment of values often sacrificed by markets: equality, community, and (above all) the right to subsistence. When market economies penetrate peasant societies, then, peasants react with moral outrage. Their defensive rejection of incorporation into the modern world economy provides a radical thrust to political protest in agrarian societies.

Rational choice theorists have attacked this argument on both empirical and logical grounds. For example, Popkin challenges Scott's depiction of the internal politics of corporate villages and demonstrates that the consequence of peasant revolution does not follow from the premise of peasant values, given the incentives to free-ride (Popkin 1979).

We focus on the logic of the arguments put forward by the moral economists. Our critique is formal and deductive; it isolates and examines the properties of an institution that we call the Rule. We aim our attack at the foundations of the moral economists' argument: the link between peasant institutions and values. In particular, we show that an archetypical institution of peasant society--the corporate village with collective rights in property--cannot logically provide a defense of the core values of peasant society: equality, community, and the guarantee of subsistence. The implication, of course, is that the moral outrage that fuels peasant revolutions must originate elsewhere than from the breakdown of this institution.

Although there are many other peasant institutions, (e.g., lineages, reciprocity, patron-client ties), other, highly complex forms of property rights, and other sources of peasant revolution, claims about what we call the Rule lie at the foundation of the moral economy argument. Hence, we have chosen to model that feature.

\section{THE MORAL ECONOMY ARGUMENT}

Central to the literature on peasant rebellions are studies of corporate villages. Corporate villages limit individual rights in property. The community restricts the rights of individual families to purchase, lease, alienate, rent, or use land. In some cases, corporate villages enforce forms of communal tenure. Land rights then remain fully vested in the community, and the village distributes the land among its members. In such cases, the corporate village may be called a repartitional commune.

While apparently relatively rare, corporate villages and repartitional communes have long attracted great attention. At least since the mid nineteenth century, scholars have written extensively about these forms of villages and made strong claims on their behalf. ${ }^{5}$ Most recently, they have played a central role in the moral economy school of peasant behavior (Migdal 1974; Scott 1976; Wolf 1973).

The Russian mir constitutes perhaps the most famous example of such an institution. We shall draw our "stylized facts" from the literature on the mir. We focus upon several features that loom large in the scholarly debates, which provide the subject of our analysis. At any given time, these features may have 
characterized some village communities but not others; or they may have been typical of the mir in one period but not in another.

The mir consisted of a collection of families who gained rights and incurred obligations through membership in a village. The most important right was to share the village's land, while the most important obligation was to share in the burden of its taxes. As the literature on the mir makes clear, the two were connected. ${ }^{6}$ The rural community was assigned a tax bill by the state, the size of which was proportional to the number of the village's souls (a soul being a working-age person). ${ }^{7}$ To meet its obligations to the state, the village then divided the tax bill among its member families while also apportioning them a share of the village's land - and thus the ability to pay the taxes.

Throughout, we will focus on the rules that governed the partitioning of village lands. Assuming the village to possess different kinds of qualities of land $K_{1}$ and $K_{2}$, the Rule assumes the following form: if a family i contains $L^{\mathrm{i}} / L=C^{\mathrm{i}} \%$ of the community's souls then that family receives $C^{i}=K_{1}^{i} / K_{1}$ of the village's land of type 1 and $C^{i}=K_{2}^{i} / K_{2}$ of the village's land of type 2 , where $L$ is the number of souls in the village, $L_{\mathrm{i}}$ is the number of souls in the family, $K_{1}$ and $K_{2}$ are the number of acres of type 1 and type 2 land in the village, and $K_{1}^{\mathrm{i}}$ and $K_{2}^{\mathrm{i}}$ are the amount of each type of land given to family $i$. In our model, type 1 land is of a better quality than type 2 .

Discussions of collective villages stress the high levels of risk that confront agrarian societies. Rains can fail; disease can infect crops, livestock, or human beings; and prices can change, lowering the purchasing power of rural households. Given their small endowments and marginal physical and economic locations, rural families facing such shocks can starve. The possibility of the loss of subsistence constantly confronts the inhabitants of poor, agrarian societies.

Noting these characteristics of the institutions and environment of collective villages, scholars develop a powerful line of argument. Their basic contention is that collective villages are social-as opposed to economic-institutions. By this they mean that the allocation of factors of production in collective villages is determined by social relationships rather than by markets. ${ }^{8}$ Land is not bought and sold; it is allocated by the community. Nor is labor a commodity to be exchanged in markets; rather, peasants draw their labor from their families. Markets thus play a limited role in the allocation of factors of production; the allocation is, instead, structured by social institutions.

From this premise, the contributors mount their first claim-that rural economies governed by collective villages generate outcomes that differ from those of markets. In particular, they do not allocate resources so as to maximize total output. The allocation of resources in such societies is not constrained to be efficient. ${ }^{9}$ A second claim is that collective villages constrain the allocation of resources so as to enable rural societies to secure certain key values-presumably values threatened by the kind of behavior necessary to achieve the maximization of the total social product. The most important of these other values is the security of subsistence. Polanyi writes, "It is the absence of the threat of individual starvation which makes primitive society, in a sense, more human than [the] market economy, and at the same time less economic" (1957, 164). Characterizing the writings of Scott, Wolf, and others, Popkin notes: "Village procedures reflect this overriding concern of peasants with survival. . The 'right to subsistence' is the primary normative concern" $(1979,11)$. Another important value secured by collective villages is justice. While not rigorously defined, the term is used in ways that imply equity and a concern with sharing. The village is a community of fortune, with no one able to control resources in ways that permanently privilege their life chances. ${ }^{10}$

In short, collective villages, based upon the division of the land among all families, are held to be "moral economies"11_in contrast to market economies, which tolerate inequality and where a person, if poor, can starve for want of access to productive resources.

\section{CRITIQUE}

As might be expected, the communal allocation of land generates allocations that represent an alternative to the outcome secured by markets, allocations that are not efficient. Contrary to what is also claimed, however, the losses in production do not generate benefits in terms of enhancing the attainment of social values in the shape of security of subsistence, equity, or the elimination of envy. The justification for the collective allocation of land must lie elsewhere.

\section{The Set-Up}

We assume that there are no markets for land or labor, land being allocated by the community and producers employing family labor; and that peasant production functions are concave. ${ }^{12}$ We also assume the existence of two forms of taxation:

1. Tax rule 1. Families are taxed according to the number of souls, that is, working-age adults in the family.

2. Tax rule 2. Families are taxed according to the size of their land holdings.

Lastly, we omit from our analysis cases in which the community's tax bill exceeds its total product. We thus rule out cases where tax rule 1 is in effect but where the land is scarce or of very poor quality. We also rule out cases where, under tax rule 2 , the receipt of additional land imposes losses upon families. In the absence of hired labor, the acquisition of additional land by a family can lead to a decline in the marginal product. Under tax rule 2 , at some point, 
the marginal product of an additional unit of land could thus be less than the increase in the tax bill resulting from its acquisition; land would then become an undesirable good. We shall assume that neither situation holds, although Wallace confirms that such situations did in fact occur in practice (1961, 283). The result is to bias the analysis in favor of the arguments in the literature, making our criticisms more telling.

\section{Efficiency}

Let there be two types or qualities of land, $K_{1}$ and $K_{2}$. Applying the Rule, each family i then receives a share of each type of land proportional to its share of the total village population; that is, if the relative size of family i is $C^{i}=L^{i} / L$, then it receives $C^{i}=K_{1}^{i} / K_{1}$ of type 1 land and $C^{i}=K_{2}^{i} / K_{2}$ of type 2 .

If we assume that production on land of each type is Cobb-Douglas, then family i's production function can be written

$$
Q^{\mathrm{i}}=\left(K_{1}^{\mathrm{i}}\right)^{\alpha_{1}}\left(L_{1}^{\mathrm{i}}\right)^{\beta}+\left(K_{2}^{\mathrm{i}}\right)^{\alpha_{2}}\left(L_{2}^{\mathrm{i}}\right)^{\beta}
$$

where $K_{1}^{i}$ and $K_{2}^{i}$ are the family's allocation of each type of land and $L_{1}^{\mathrm{i}}$ and $L_{2}^{\mathrm{i}}$ are the family's allocation of its labor $L^{\mathrm{i}}\left[L^{\mathrm{i}}=L_{1}^{\mathrm{i}}+L_{2}^{\mathrm{i}}\right]$ across its holdings of the two types of land. ${ }^{13}$

Allocating its resources optimally, each family i will shift workers between plots until the marginal product of labor is equal on each type of land. But when individual families behave rationally and maximize their total production, the result is not "socially rational" in the sense of maximizing the total product of the village community. To see this, note that seeking to optimize, each family will devote labor to its land of type 1 until

$$
\left(\frac{L^{\mathrm{i}}-L_{1}^{\mathrm{i}}}{L_{1}^{\mathrm{i}}}\right)^{1-\beta}=\frac{\left(K_{2}^{\mathrm{i}}\right)^{\alpha_{2}} 14}{\left(K_{1}^{\mathrm{i}}\right)^{\alpha_{1}}} .
$$

For a given family, the optimum use of labor on land of a given type is thus a function of its total endowment of land of all types. Given that land is allocated among the different families according to the Rule, the size of this endowment will vary among families.

The community allocates land so as to equalize the land-labor ratio across families for each kind of land; each family, behaving optimally, equalizes the marginal product of its labor on the two kinds of land. The result is that the community's allocation does not yield behavior by families (even though they optimize) that produces marginal products of land and labor that are identical for all families. Given that labor is not traded, we cannot expect subsequent reallocations of labor to equalize the marginal products of land among the village families. And given that land is not traded, we cannot expect subsequent reallocations of land to equalize the marginal products of family labor. The first-order conditions for the maximization of the total community product, therefore, would not hold, given the Rule, even though each peasant family might allocate its own land and labor so as to maximize the total family product.

The implication is that one of the claims of the moral economy is correct. Imposing rules to equalize the allocation of land per laborer, communal villages do indeed achieve outcomes that fail to maximize the productive use of their resources. As claimed in the literature, such communities abide by principles other than those embodied in the market. A key question then becomes whether (as is also claimed) the resultant allocation, while economically costly, is socially desirable, in that it supports the attainment of noneconomic values.

\section{Subsistence Guarantees}

A key value that communal institutions are supposed to provide is the guarantee of subsistence. However, the rule of allocating land to a family in proportion to the number of souls fails to provide that guarantee. Most obviously, in a bad year the Rule could not guarantee subsistence: guarantees of access to land would not guarantee access to output; for with natural calamities, production could fail. Under such circumstances, few systems could succeed. In fairness, then, the Rule should be subject to a less demanding test.

One test is the ability to underpin the subsistence needs of less fortunate families, that is, those with low marginal products. We can define subsistence needs as $s n+t$, where $n$ is the number of mouths to feed, $s$ the subsistence requirements of each "mouth," and t the tax bill. It is possible, of course, that members of a family could be so incapacitated that no amount of land, if operated by its members, could yield sufficient output to meet its subsistence needs. ${ }^{15}$ It is also possible that the marginal product of labor of the family could be so low that given the increase in its tax bill (under tax rule 2) associated with the acquisition of additional land, the subsistence needs of the family would be imperiled by the receipt of greater amounts of land. ${ }^{16}$ Even apart from such problems, there remains an additional difficulty: the lower the productivity of a family's labor, the greater the amount of land it requires to meet its subsistence target. Should the community seek to provide unfortunate families with sufficient land to meet their subsistence needs, it would have to reduce the amount of land supplied to other families. In seeking to guarantee the subsistence needs of its unfortunate families, in other words, it would necessarily place the subsistence needs of others at greater risk.

To illustrate, we once again assume that family production functions are Cobb-Douglas. Then, solving for the maximum possible total output yields an expression for the conditions necessary to guarantee subsistence: 


\section{TABLE 1}

Applying the Rule: Equity, Envy, and Guarantee of Subsistence

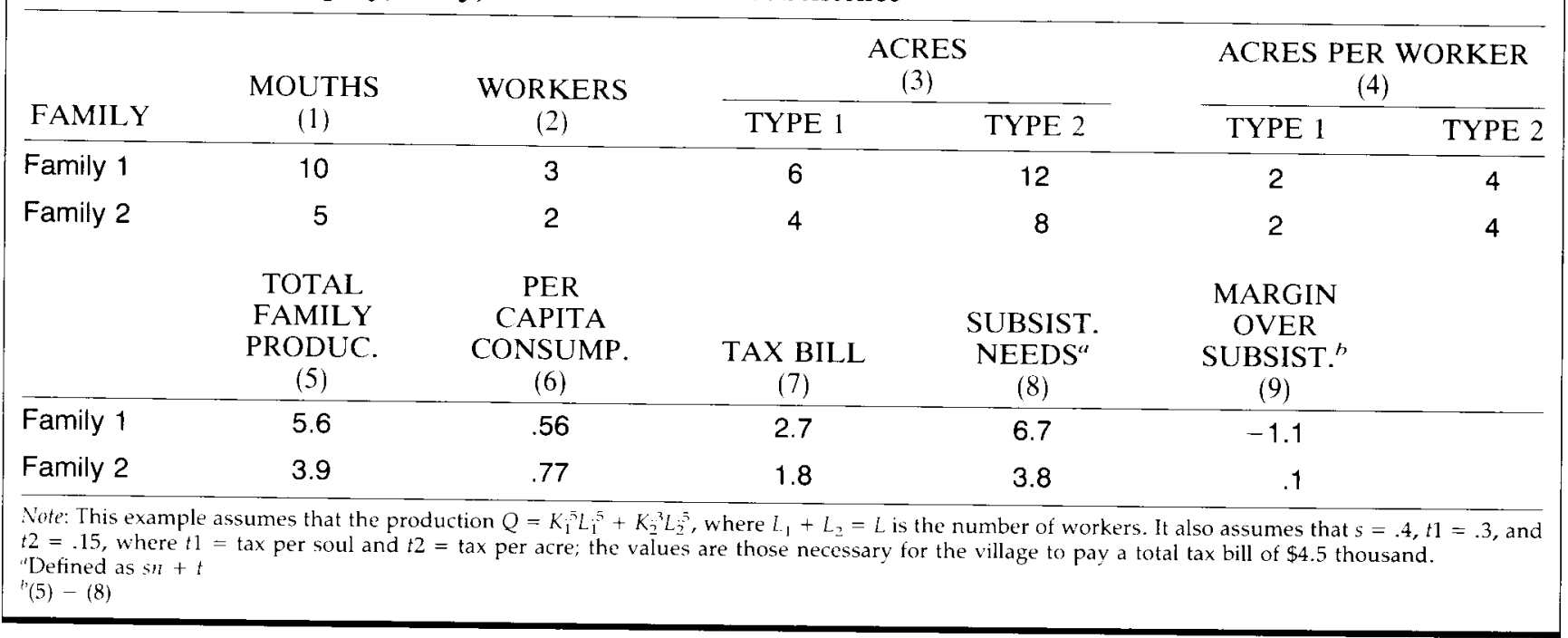

$L_{\mathrm{i}}^{\beta}\left(K_{1}^{\mathrm{i}\left(\alpha_{1}\right) /(1-\beta)}+K_{2}^{\mathrm{i}\left(\alpha_{2} / /(1-\beta)\right.}\right)^{1-\beta} \geq s n+t$

for every $\mathrm{i}$.

Clearly, families with low values of $L^{i}$ would require larger quantities of $K_{1}^{\mathrm{i}}$ and $K_{2}^{\mathrm{i}}$. If

$$
\sum_{\mathrm{i}} K_{1}^{\mathrm{i}}>K_{1} \quad \text { and/or } \quad \sum_{\mathrm{i}} K_{2}^{\mathrm{i}}>K_{2}
$$

for every possible combination of $K_{1}^{\mathrm{i}}$ and $K_{2}^{\mathrm{i}}$ satisfying the above inequality, then the requirements for guaranteeing the subsistence needs of all families cannot be met. ${ }^{17}$

The Rule, then, does not, in general, provide subsistence guarantees. It can do so only under specific conditions, such as those just specified. It is important to note that these conditions are more restrictive the poorer the village community: the lower the quality of the land, or the poorer the quality of the labor, or the higher the tax bill, the smaller (according to expression 1) the margin over and above subsistence needs. The poorer the community, in short, the lower the margin left for it to secure the subsistence requirements of its least productive members while not imperiling the needs of others. Hence, applying the Rule cannot guarantee subsistence. In fact, it can increase the degree to which subsistence is threatened. And this threat becomes more severe, the poorer the rural community.

\section{Other Values}

By reducing the efficiency of land use, corporate villages impose economic costs. We have argued that these costs are not offset by the major benefit often claimed for them, namely, that unlike the market, corporate villages can guarantee that rural dwellers will not starve. In this sense, we can reject the claim that this alternative to the market is "more human" even though "less economic" (Polanyi 1957, 164).
Perhaps, then, the justification of communal villages lies in their ability to secure allocations that support the attainment of other values: the promotion of equality, the reduction of envy, or the strengthening of the potential for community. In exploring this possibility, we employ an example (Table 1). The example consists of a village containing two families living on 30 acres of land. One family has twice as many mouths to feed as the other: 10 for family 1,5 for family 2 . The families also differ in the number of souls (working-age persons): three for family 1 , two for family 2 . The village lands are of two types. The village is liable for a total tax bill of $\$ 4.5$ thousand, which it assigns to its member families either by the number of souls belonging to the family or by the amount of land that the family farms. ${ }^{18}$ Applying the Rule, the village then allocates to the two families shares in each type of land, the size of the share depending on the proportion of the village's souls who are members of the family. Family 1 therefore receives 6 acres of land of type 1 and 12 acres of land of type 2 . Family 2 , having two-thirds of the number of workers as family 1 , receives 4 acres of land of type 1 and 8 acres of land of type 2 (Table 1 , col. 3).

We can now examine the impact of the Rule upon equality, envy, and the attainment of subsistence. We assume a Cobb-Douglas production function with constant returns to scale, with arbitrarily selected parameter values. The validity of this counterexample rests solely upon the assumption of concavity, however. ${ }^{19}$

From column 4, it is clear that applying the Rule equalizes access to the means of production. As a consequence, neither family could envy the other's land endowment. Columns 5 and 6 remind us of an elementary but important truth, however: equality of land endowments fails to guarantee either equality of total product or equality of consumption. Family 1 
TABLE 2

Payoffs Under Given States of Nature and Types of Land

\begin{tabular}{lcc}
\hline TYPE OF & \multicolumn{2}{c}{ STATES OF NATURE } \\
\cline { 2 - 3 } LAND & GOOD YEAR & BAD YEAR \\
\hline Type 1 & 4 & 1 \\
Type 2 & 3 & 2 \\
\hline
\end{tabular}

contains more workers, gets more land, and therefore produces more output; family 2 could therefore envy its neighbor's production. But family 1 also possesses more members; its members would therefore envy the consumption of members of family 2, who, having a lower ratio of consumers to producers, consume more per capita, even with their lower total product.

The general point is obvious: producing equality in one aspect of economic life, the Rule generates inequality in another. Insofar as the attainment of community requires the reduction of envy, the Rule, therefore, fails to provide the institutional foundations for a community in rural life.

In recognition of this point, some-especially James Scott (1976)-stress the significance of envy in rural life. They emphasize the jealousy faced by those who prosper and the pressures mounted upon the prosperous to divest themselves of accumulated assets by sponsoring public festivals and private clients. Insofar as these behaviors characterize the life of communal villages-i.e. villages governed by the Rule-they underscore the failure of this institution to promote community by reducing envy.

The example illustrates a last point, one made in the previous section. As seen in column 9, the Rule fails to equalize subsistence risk, much less to guarantee subsistence. It gives family 1 insufficient land to feed itself and pay its taxes.

\section{AN ALTERNATIVE INTERPRETATION}

Alternatively, we argue, constraints placed on the initial allocation of land could be construed as providing not guarantees but, rather, insurance. ${ }^{20}$ The Rule could provide a form of insurance that equalizes the subjective impact of the variability of nature, thereby rendering villages communities in the sense of communities of (mis)fortune.

Consider Table 2. ${ }^{21}$ Nature provides good years and bad. There are two types of land. Type 1 does better than type 2 in good years but worse than type 2 in bad. The application of the Rule ensures that every family will hold the two types of land in the same proportion; that is, for families $i$ and $j, K_{1}^{i} / K_{2}^{i}=$ $K_{1}^{j} / K_{2}^{i}=K_{1} / K_{2}=\gamma$. As suggested in Table 2, the production achieved by a family depends upon how much of each type of land it holds and whether the year is good or bad. If good, then family i's produc- tion will be $4 K_{1}^{\mathrm{i}}+3 K_{2}^{\mathrm{i}}$, which (given that $K_{1}^{\mathrm{i}}=\gamma K_{2}^{\mathrm{i}}$ ) can be rewritten as $K_{2}^{\mathrm{i}}(4 \gamma+3)$. Reasoning in a similar fashion, family i's production in a bad year will be $K_{2}^{i}(\gamma+2)$.

The consequence of equalizing the proportion of the two types of land in the endowments of each family is that should a bad year occur, each family experiences the same regrets. ${ }^{22}$ For each family $i$, the difference in the production between a good year or bad is $K_{2}^{\mathrm{i}}(4 \gamma+3)-K_{2}^{\mathrm{i}}(\gamma+2)=K_{2}^{\mathrm{i}}(3 \gamma+1)$, yielding a percentage loss of $(3 \gamma+1) /(4 \gamma+3)$. In the absence of the Rule, $\gamma$ would differ across families. Each family i's percentage loss in a bad year would then be $\left(3 \gamma^{j}+1\right) /\left(4 \gamma^{i}+3\right)$; and because $\gamma^{i}$ varies across families $\gamma^{j}$, each family would experience different levels of regret under unfavorable states of nature.

The equalizing impact of the Rule upon land endowments therefore equalizes regrets in the face of unpredictable nature. This result represents a "positive" finding and, indeed, is the first positive result of this analysis. It should be noted, however, that it generates an interesting contradiction. ${ }^{23}$

We have already demonstrated that the Rule, while guaranteeing equality of endowments, cannot guarantee equality of production (or consumption). Therefore, by generating equal percentage losses (or gains) in the face of random shocks by nature, the Rule preserves these inequalities. Once ranked by production levels, when shocked by variations in nature, peasant families subject to the Rule would find their ranks preserved; for they would experience equal proportional gains or losses. We thus encounter a contradiction: the Rule equalizes regrets but at the expense of preserving inequalities in production and consumption.

One response is deeper skepticism about the claims in the moral economy literature concerning peasant equality. A more charitable response (which, indeed, we favor) is to garner an insight into peasant attitudes toward equality. Inequality is tolerable in agrarian societies so long as no family can gain relative to another as a result of the random acts of nature.

\section{CONCLUSION}

Claims about peasant society lie at the core of theories of peasant revolution. They also lie at the heart of debates between competing schools of scholarship. In particular, debates between the moral economy and rational choice theories of peasant revolution focus on one of the central institutions of peasant society, the corporate village.

We have returned to the literature on corporate villages, abstracted an idealized representation of a core property of that institution (the Rule), and examined its ethical features. We have found that (as claimed by their advocates) villages applying the Rule secure land allocations that result in outcomes differing from those that would be achieved by markets, namely, inefficient outcomes. But we find reasons to contest other claims made by the moral economists. 
The economic costs incurred by using the Rule do not secure the attainment of other values, such as guarantees of subsistence, greater equality, or a greater sense of community resulting from the elimination of envy. In the face of high levels of risk, however, the form of collective property rights embodied in the Rule may create communities of (mis)fortune, in which no one can envy the gains of others resulting from random shocks of nature.

Our formal exploration of central arguments in the peasant literature yields two further lessons. The sense of moral outrage that impels peasants to violence cannot result from the breakdown of institutions based upon conventions resembling the Rule; for we have shown that such institutions cannot underpin the realization of the social values that provide the radical impetus to revolution. In light of this finding, the analysis also underscores the danger of basing theories of peasant revolutions on idealized images of self-contained peasant communities. ${ }^{24}$ Theories of peasant revolution might better be based on the analysis of conflicts between peasants and "external" agents, such as exploiting classes or extracting states. In this sense, our analysis suggests explaining peasant revolutions by relying less on studies of the internal culture of peasant communities and more on studies of their external political and economic relations.

Fruitful extensions of our theory would include comparative analysis. The behavior of the Rule should be compared to that of the market. For given distributions of land and compositions of households and given distributions of random interventions by nature, the Rule might well secure socially desirable outcomes with a greater likelihood than the market. Our negative findings might appear less damaging, then, when subject to comparative analysis. Similarly, our investigation of the Rule should be replicated for other peasant institutions, such as lineages (Bates 1990; Posner 1980); common pool resource systems for water, forests, and grazure (Ostrom 1990); and share tenancy contracts (Stiglitz 1986). Only in this way can we fully assess the implications for the claims by the moral economists. Whereas one might argue that should the claims not hold for something as rigorously egalitarian as the Rule, then, a fortiori, they are unlikely to hold for other peasant institutions, another might reply that while the claims might not hold for this particular, highly stylized version of the Rule, they may hold for other institutions. We cannot resolve the matter, then, until we analyze these other institutions.

In addition to comparative analysis, we need to investigate the Rule itself more deeply. In what sense might it represent a "best response" by the members of a peasant community to a government-imposed tax? If, under the Rule, poor people could not advance relative to rich (given random acts of nature) why, then, would the Rule be chosen by a peasant community? We need answers to such questions.

\section{Notes}

Bates was a fellow at the Rockefeller Foundation's Bellagio Study and Conference Center and then John M. Olin visiting professor at the Graduate School of Business at Stanford University during the time of writing. Research was supported by National Science Foundation grant SES-8821151. We wish to thank John Aldrich, Joel Barkan, Raquel Fernandez, Arun Agrawal, Emerson Niou, John Quiggin, James C. Scott, James Sloat, and Peyton Young for comments.

1. De Janvry (1981) offers a sophisticated version. More representative would be the interpretive sections of Barnett and Njama 1966 or Palmer and Parsons 1977.

2. Lenin's Development of Capitalism in Russia (Lenin 1964) stood as parent to this tradition, just as his Imperialism (1924) stood as parent to the dependency school. Some of the most interesting studies of rural accumulation and class formation come out of Africa. See, e.g., the contributions to the peasant debate in Review of African Political Economy 20 (1981).

3. Most notably, perhaps, Migdal 1974; Scott 1976; and Wolf 1957, 1973.

4. Most notably, Popkin 1979; see also Bates 1976.

5. See, e.g., the debates between the backers of Baron Haxthausen and B. N. Chicherin, summarized in Blum 1961, $508 \mathrm{ff}$.

6. This discussion draws on Blum 1961, 1971; Robinson 1949; and Wallace 1961.

7. Occasionally, an adult couple was defined as one soul.

8. The most notable development of this argument is that of Polanyi 1957. An influential amplification and elaboration is contained in Dalton 1971. See also Migdal 1974; Scott 1976: and Wolf 1957, 1973.

9. In typically vivid language, Eric Wolf distinguishes between collective villages and market economies: "Capitalism cut[s] through the integument of custom, severing people from their accustomed social matrix in order to transform them into economic actors, independent of prior social commitments to kin and neighbors. They [have] to learn how to maximize returns and how to minimize expenditures, to buy cheap and to sell dear, regardless of social obligations and social costs"' $(1973,279)$.

10. For a vivid recreation of the power of this ethic, see Hinton 1972

11. The phrase is, of course, Scott's (1976).

12. We employ a Cobb-Douglas production function throughout. In the extended example (Table 1), we impose an even more restrictive assumption, namely, that production functions are not only Cobb-Douglas but also possess constant returns to scale. We make these assumptions in order to generate numerical results. Our arguments, however, unlike our illustrations, depend not upon the specific form of the production function but solely on its being concave.

13. Note that we are assuming that the form of the production function is similar on each type of land. This might not be the case if, say, one type of land were used for arable production and the other for pastoral. See also n. 12 .

James Scott, in a personal communication, indicates that the communal villages of Russia re-allocated land and labor that were "slack," with the result that the process of production in practice approximated the pattern that would prevail, had inputs been allocated through factor markets.

14. This result does not depend upon the assumption of maximizing behavior by the individual families. Using a Chayanov-type production function for the peasant household, for example, would only strengthen the result (Thorner, Kerblay, and Smith, 1966). Secondly, there is some evidence that following the initial allocation of land in accordance with the Rule, farm families did exchange portions of their land holdings (Robinson 1949, 112). These transactions, however, appear to have been limited and unauthorized and not to have fundamentally altered the initial allocation.

15. That is, the total product secured by a family, even with infinite amounts of land, would lie below $s h+t$. 
16. As noted by Robinson under tax rule 2, such families would be placed at risk by being given more land $(1949,274)$.

17. Note that allowing laborers to have varying productivity levels will not alter this result.

18. In practice, given that the Rule allocates an amount of land to each family in proportion to the number of souls, the tax bill assigned each family is identical under the two tax systems (see col. 7).

19. The choice of specific values for the parameters of the production function are arbitrary. So, too, is the choice of a numerical value for $s$. The values of $t 1$ and $t 2$ are determined once the number of souls, the quantity of land, and the size of the tax bill are given.

20. The locus classicus of this approach remains McClosky 1976. For a critique, see Dahlman 1980. See also the very interesting work of Quiggin 1988.

21. The argument follows if (as would be natural in the context of the problem), the following general relationships hold: the cells of Table 2 are labeled $a, b, c$, and $d$ (left to right; $a, b$ in top row; $c, d$ in bottom row), and $a>b, c>d, a>c$, and $a>b$.

22. It is important to stress that we do not mean vespets in the same sense as in decision theory. Our agents, after all, have no choices and so cannot regret their choice of strategies. Rather, by regrets we mean losses by comparison to what they could have received in a good year

23. Note, as well, a less charitable interpretation, namely, that the Rule prevents a shift in the relative rankings of the village families, measured in terms of output, as a consequence of a random shock from nature.

24 . It thus joins the criticism of the political economists who criticize traditional anthropological studies of peasant villages, treating them in abstraction from broader political and social forces. See, e.g., the critique contained in Wolf 1973.

\section{References}

Barnett, Don, and Karari Njama. 1966. Mau Mau from Within. New York: Monthly Review.

Bates, Robert H. 1976. Rural Responses to Industrialization. New York: Yale University Press.

Bates, Robert H. 1990. "Capital, Kinship, and Conflict." Canadian Journal of African Studies 24:151-64.

Blum, Jerome. 1961. Lord and Peasant in Russia. Princeton: Princeton University Press.

Blum, Jerome. 1971. "The European Village as Community: Origins and Functions." Agricultural History 45:157-78.
Dahlman, Carl J. 1980. The Open Field System and Beyond. Cambridge: Cambridge Liniversity Press.

Dalton, George. 1971. Economic Anthropology and Development. New York: Basic Books.

De Janvry, Alain. 1991. The Agrarian Question and Reformism in Latin America. Baltimore: Johns Hopkins University Press.

Hinton, William. 1972. Fanshen: A Documentary of Recolution in a Chinese Villaye. New York: Monthly Review.

Lenin, Vladimir I. 1924. Imperialssm: The Latest Stage in the Detelopment of Canitalism. Trans. Y. T. Kozlowski. Detroit: Marxian Educational Society.

Lenin, Vladimir I. 1964. The Derelopment of Capitalism in Russia. Moscow: Progress.

McClosky, Donald M. 1976. "English Open Fields as Behavior Toward Risk." In Research in Economic Historu, vol. 1, ed. Paul Uselding. Greenwich, CT: JAI

Migdal, Joel S. 1974. Politics and Revolutions. Princeton: Princeton University Press.

Moore, Barrington. 1966. Social Origins of Dictatorship and Democracy. Boston: Beacon.

Ostrom, Elinor. 1990. Goterning the Commons. Cambridge: Cambridge University Press.

Palmer, Robin, and Neil Parsons, eds. 1977. The Roots of Rural Pocerty in Central and Southern Africa. Berkeley: University of California Press.

Polanyi, Karl. 1957. The Great Transformation. Boston: Beacon.

Popkin, Samuel L. 1979. The Rational Peasant. Berkeley: University of California Press.

Posner, Richard. 1980. "A Theory of Primitive Society." Journal of Law and Economics 23:1-53.

Quiggin, John. 1988. "Scattered Land Holdings in Common Property Systems." Iournal of Economic Behavior and Oryanization. 9:187-201.

Robinson, Geriod T. 1949. Rural Russia Under the Old Regime. New York: Longman Green.

Scott, James C. 1976. The Moral Economy of the Peasant. New Haven: Yale University Press.

Stiglitz, Joseph. 1986. "The New Development Economics." Worlt Development 2:257-65.

Thorner, Daniel, Basile Kerblay, and Robert E. F. Smith. 1966. Chayanon on the Theory of Peasant Economy. Homewood, IL: Irwin.

Wallace, Donald Mackenzie. 1961. Russin on the Eve of War and Rerolution. New York: Vintage Books.

Wolf, Eric R. 1957. "Closed Corporate Peasant Communities in Mesoamerica and Central Java." Southwestern Journal of Anthropology 13:1-18.

Wolf, Eric R. 1973. Peasant Wars of the Twentieth Century. New York: Harper.

Robert H. Bates is Henry R. Luce Professor of Political Science, Duke University, Durham, NC 27706.

Amy Farmer Curry is Assistant Professor of Economics, University of Arkansas, Fayetteville, AR 72701. 